\title{
PENGARUH GENDER FINANCIAL EXPERTISE KOMITE AUDIT TERHADAP PRAKTIK MANAJEMEN LABA PERUSAHAAN NON- KEUANGAN YANG TERDAFTAR DI BEI PERIODE 2016-2018
}

\author{
Flaviana Agustiani Yuniargo ${ }^{*}$, Senny Harindahyani ${ }^{2}$ \\ ${ }^{1,2}$ Fakultas Bisnis dan Ekonomika, Universitas Surabaya, Surabaya, \\ Indonesia
}

DOI: https://doi.org/10.24123/jati.v14i8

\begin{abstract}
Earnings management is a manager's choice to choose accounting policies or real actions to achieve certain earnings goals. This study aims to examine the effect of the gender financial expertise of the audit committee on earnings management practices. This study uses 852 samples of non-financial companies listed on the Indonesia Stock Exchange in 2016-2018 by using multiple linear regression analysis with classical assumption testing. The result of this study is the indication that committee audit financial expertise (EXPERT), proportion of the number of women on the audit committee (ACFD), and proportion of female financial experts on the audit committee (FEMEX) do not have a significant influence on earnings management as measured by using discretionary accruals. On the contrary, the proportion of male financial experts on the audit committee (MALEX), has a significant positive effect on earnings management. This shows that the presence of financial expertise that affects earnings management has been influenced by the sex of male financial experts. This research is in accordance with the theory that reveals that there are different effects with the existence of gender differences in a company.
\end{abstract}

Keywords: Audit Committee; Financial Expertise; Gender; Gender Expertise.

\begin{abstract}
Abstrak
Manajemen laba adalah pilihan manajer untuk memilih kebijakan akuntansi atau tindakan nyata untuk mencapai tujuan penghasilan tertentu. Penelitian ini bertujuan untuk menguji pengaruh keahlian keuangan gender komite audit terhadap praktik manajemen laba. Penelitian ini menggunakan 852 sampel perusahaan non-keuangan yang terdaftar di Bursa Efek Indonesia pada tahun 2016-2018 dengan menggunakan analisis regresi linier berganda. Hasil dari penelitian ini adalah indikasi bahwa keahlian keuangan komite audit (EXPERT), proporsi jumlah perempuan dalam komite audit (ACFD), dan proporsi ahli keuangan perempuan pada komite audit (FEMEX) tidak memiliki pengaruh yang signifikan dengan manajemen laba yang diukur menggunakan discretionary accruals. Sebaliknya proporsi ahli keuangan pria pada komite audit (MALEX), memiliki pengaruh positif yang signifikan terhadap manajemen laba. Ini menunjukkan bahwa keberadaan keahlian keuangan yang memengaruhi manajemen laba telah dipengaruhi oleh jenis kelamin keahlian keuangan pria. Penelitian ini sesuai dengan teori yang mengungkap bahwa ada pengaruh yang berbeda dengan adanya perbedaan gender dalam suatu perusahaan.
\end{abstract}

Kata Kunci: Gender; Gender Expertise; Keahlian Keuangan; Komite Audit.

*Korespondensi: s130316333@student.ubaya.ac.id 


\section{PENDAHULUAN}

Skandal akuntansi terbesar yang menimpa salah satu perusahaan terbesar di Amerika yaitu Enron Corporation, telah membuat kepercayaan masyarakat terhadap profesi akuntan menurun. Kasus yang terjadi pada Enron bermula pada laporan keuangan di tahun 2000 yang dicurigai telah dimanipulasi. Kasus mengenai manipulasi dalam penyajian laporan keuangan selama beberapa tahun terakhir juga telah menyita perhatian publik di Indonesia, salah satunya adalah kasus yang terjadi pada PT. Sunprima Nusantara Pembiayaan (SNP Finance) di akhir tahun 2018 dan Garuda Indonesia yang mulai muncul di awal tahun 2019. SNP Finance dikabarkan telah menerima sanksi dari Otoritas Jasa.

Dengan adanya banyak skandal akuntansi seperti Enron, di tahun 2002 terbentuklah Sarbanes-Oxley Act of 2002 atau yang sering disebut dengan SOX. SOX merupakan peraturan yang ditujukan kepada perusahaan terbuka yang berada di bursa saham Amerika. Salah satu yang dibahas dalam SOX adalah otoritas manajemen mengenai auditor yang diberikan kepada komite audit untuk meningkatkan kualitas laporan keuangan (Simbolon, 2010). Peraturan OJK Nomor 55/POJK. 04/2015 tentang pembentukan dan pedoman pelaksanaan kerja komite audit dalam pasal 7 (e) menyatakan bahwa anggota komite audit wajib memiliki paling sedikit satu anggota yang memiliki latar belakang pendidikan dan keahlian di bidang akuntansi dan keuangan. Selain itu The Blue-Ribbon Committee on Improving the Effectiveness of Corporate Audit Committee (BRC) (Zhang et al., 2004) menyatakan bahwa setiap komite audit sekurangkurangnya harus memiliki satu pakar keuangan sebagai salah satu keahlian dari anggota komite audit.

Penelitian mengenai keahlian keuangan komite audit mampu mengurangi manajemen laba telah menjadi banyak subjek penelitian dengan berbagai macam hasil, namun yang menjadi perhatian adalah tidak ada yang membedakan antara jenis kelamin para ahli keuangan di komite audit (Zalata et al., 2018). Oleh karena itu di tahun 2018, Zalata et al. melakukan penelitian mengenai bagaimana keahlian keuangan mempengaruhi manajemen laba dengan mempertimbangkan jenis kelamin komite audit pada 5660 perusahaan di Amerika Serikat. Hasil penelitian ini adalah bahwa proporsi ahli keuangan perempuan di komite audit secara signifikan mempengaruhi dalam mengurangi manajemen laba dengan proporsi ahli keuangan laki-laki di komite audit tidak berpengaruh secara signifikan dalam manajemen laba. Sehingga bisa saja pada penelitian sebelumnya yang menyatakan bahwa keahlian komite audit 
mempengaruhi manajemen laba dikarenakan adanya proporsi jumlah perempuan dalam komite audit tersebut.

Oleh karena itu dalam penelitian ini, peneliti ingin memfokuskan pada proporsi jenis kelamin ahli keuangan komite audit di perusahaan yang terdaftar di Bursa Efek Indonesia (kecuali sektor keuangan) pada tahun 2016-2018. Diharapkan hasil penelitian ini dapat memperluas penelitian yang terdahulu dan membantu perusahaan dalam mempertimbangkan klasifikasi komite audit yang dapat membantu perusahaan dalam meningkatkan kualitas laporan keuangan yang dikhususkan pada pengurangan manajemen laba yang akan memberikan dampak negatif kepada para pemegang kepentingan perusahaan. Selain itu, penyusunan anggota yang tepat dapat menuntun komite audit mencapai performa terbaik, serta memaksimalkan kinerja manajemen dan auditor eksternal. Komite audit yang dibentuk dengan komposisi yang tepat diharapkan dapat meningkatkan kualitas tata kelola perusahaan, yang diharapkan sejalan dengan Agency Theory.

\section{RANCANGAN HIPOTESIS}

\section{Keahlian Keuangan Komite Audit dan Manajemen Laba}

Badolato et al. (2014) menemukan bahwa komite audit yang memiliki keahlian keuangan akan mengurangi level manajemen laba. Hasil penelitian ini juga sama dengan penelitian yang dilakukan oleh Zalata et al. (2018), yang menyatakan bahwa terdapat pengaruh yang signifikan antara keahlian keuangan komite audit dan manajemen laba. Penelitian dari Xie et al. (2003) juga mendukung pernyataan dan rekomendasi SEC anggota komite audit akan menjadi independen dengan adanya latar belakang keuangan yang dimiliki. Berdasarkan pada penelitian sebelumnya, maka ditemukan adanya pengaruh yang positif antara keahlian keuangan komite audit dan manajemen laba yang diukur menggunakan discretionary accrual. Oleh karena itu hipotesis yang dirumuskan adalah sebagai berikut:

H1: Keahlian Keuangan Komite Audit Menurunkan Manajemen Laba

\section{Gender (Laki-laki dan Perempuan) dan Manajemen Laba}

Adams dan Ferreira (2009) menemukan bahwa keberagaman gender memiliki pengaruh terhadap input dewan. Dalam perilaku kerja perempuan cenderung memiliki perilaku yang berbeda jika dibandingkan laki-laki. Sebagai contoh, dengan adanya dewan perempuan 
maka masalah presentasi ketidakhadiran laki-laki menjadi lebih kecil. Selain itu Adams dan Ferreira (2009) juga menemukan bahwa perempuan lebih cenderung ditempatkan pada tugas pengawasan seperti melakukan pengauditan dibanding laki-laki. Barua et al. (2010) menyatakan bahwa dalam penelitiannya CFO dengan perbedaan gender akan berpengaruh dalam berbagai pengaturan keputusan, sikap pengambilan risiko, penilaian keuangan, dan kepatuhan terhadap peraturan. Sehingga berdasarkan penelitian sebelumnya, maka dapat disimpulkan bahwa perbedaan gender (jenis kelamin) dapat memiliki pengaruh pada manajemen laba yang dilakukan perusahaan. Lebih dalam lagi dalam hal ini difokuskan pada perbedaan gender (jenis kelamin) dalam keanggotaan komite audit. Oleh karena itu hipotesis yang dirumuskan adalah sebagai berikut:

H2 : Gender (jenis kelamin) komite audit menurunkan manajemen laba

\section{Jenis Kelamin Para Ahli Keuangan Komite Audit dan Manajemen Laba}

Di tahun 2018 Zalata et al. melakukan penelitian mengenai bagaimana jenis kelamin para ahli keuangan komite audit pada 5660 perusahaan di Amerika Serikat. Hasil penelitian ini menunjukkan bahwa proporsi ahli keuangan perempuan di komite audit secara signifikan mempengaruhi dalam mengurangi manajemen laba dengan proporsi ahli keuangan laki-laki di komite audit tidak berpengaruh secara signifikan dalam manajemen laba, dalam penelitian ini manajemen laba diukur menggunakan model McNichols (2002).

Ahli keuangan perempuan lebih cenderung untuk menentang keputusan pelaporan keuangan CEO sehingga dapat menurunkan manajemen laba, khususnya di masyarakat yang memiliki litigasi industri yang tinggi. Dalam litigasi industri, risiko dari litigasi memotivasi ahli keuangan perempuan pada direktur melakukan pengawasan yang ketat untuk menghindari kemungkinan adanya kegagalan laporan (Zalata et al., 2018).

Berdasarkan dari penelitian yang dilakukan oleh Zalata et al. (2018), maka dapat disimpulkan bahwa proporsi gender (jenis kelamin) para ahli keuangan komite audit memiliki pengaruh yang signifikan terhadap manajemen laba. Berdasarkan hasil penelitian sebelumnya maka peneliti ingin melakukan penelitian yang lebih difokuskan lagi pada proporsi gender (jenis kelamin) para ahli keuangan komite audit apakah memiliki dampak pada manajemen laba, jika diteliti secara lebih menyeluruh pada semua sektor (kecuali keuangan) pada 
perusahaan yang terdaftar di BEI pada tahun 2016-2018. Oleh karena itu hipotesis yang dirumuskan adalah sebagai berikut:

H3a: Proporsi ahli keuangan perempuan menurunkan manajemen laba

H3b: Proporsi ahli keuangan laki-laki menurunkan manajemen laba

\section{METODE PENELITIAN}

\section{Populasi dan Sampel}

Metode pengambilan sampel penelitian ini menggunakan non-probability sampling dengan teknik purposive. Kriteria -kriteria yang digunakan dalam pengambilan sampel yaitu sebagai berikut:

1. Perusahaan go-public yang terdaftar dalam Bursa Efek Indonesia (BEI) dan menerbitkan annual report tahun 2016 sampai 2018.

2. Perusahaan go-public yang memiliki data yang dibutuhkan secara lengkap pada penelitian.

3. Menerbitkan annual report dengan satuan mata uang rupiah.

\section{Definisi Operasional dan Pengukuran Variabel}

\section{Manajemen Laba (DA)}

Manajemen laba berbasis akrual dapat diukur dengan adanya discretionary accrual (Zang, 2012). Penelitian ini mengukur discretionary accrual dengan menggunakan model Kothari (2005). Perhitungan discretionary accrual diperoleh dari selisih antara total akrual dan non-discretionary accrual yang dirumuskan sebagai berikut:

$$
D A_{i, t}=\frac{T A C C_{i, t}}{T A_{i, t-1}}-N D T A_{i, t}
$$

Dengan perhitungan total accrual menggunakan rumus :

$$
\frac{T A C C_{i, t}}{T A_{i, t-1}}=\beta_{1} \frac{1}{T A_{i, t-1}}+\beta_{2} \frac{(\Delta S A L E S-\Delta A R)_{i, t}}{T A_{i, t-1}}+\beta_{3} \frac{P P E_{i, t}}{T A_{i, t-1}}+\beta 4 \frac{R O A_{i, t-1}}{T A_{i, t-1}}+\varepsilon_{i, t}
$$

Keterangan:

TACC $_{\mathrm{i}, \mathrm{t}}=$ Total Akrual yang diperoleh dari Net Income - Operating

Cash Flow

$\mathrm{TA}_{i, t-1}=$ Total Aset Perusahaan $i$ pada tahun $t-1$ 


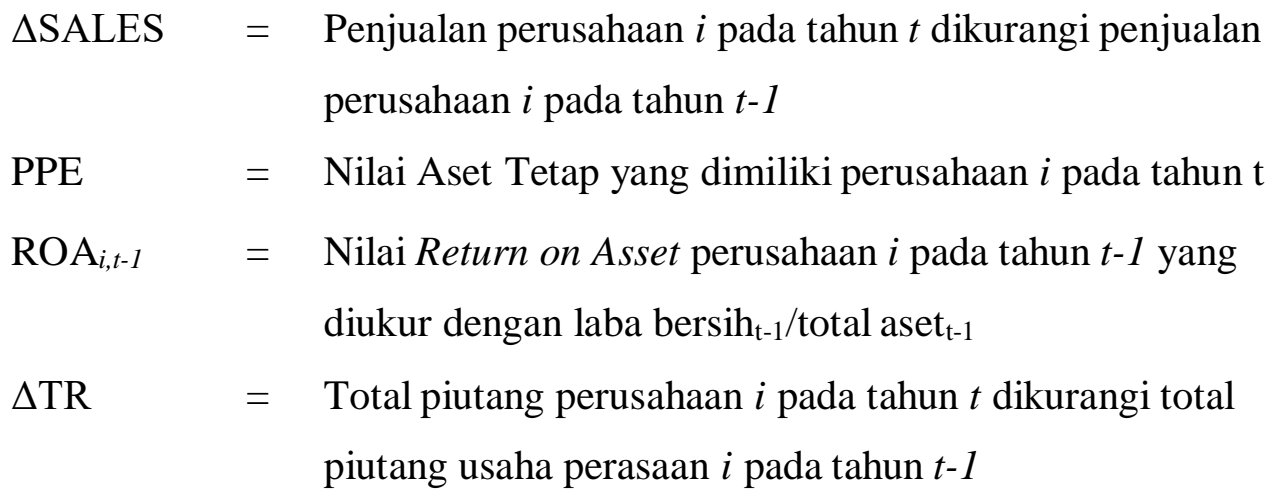

Kemudian untuk mencari nilai non-discretionary accruals dirumuskan sebagai berikut:

$$
N D T A_{i, t}=\beta_{1} \frac{1}{T A_{i, t-1}}+\beta_{2} \frac{\left(\Delta S A L E S_{i, t}-\Delta T R_{i, t}\right)}{T A_{i, t-1}}+\beta_{3} \frac{P P E_{i, t}}{T A_{i, t-1}}+\beta 4 \frac{R O A_{i, t-1}}{T A_{i, t-1}}+\varepsilon_{i, t}
$$

\section{Keahlian Keuangan Komite Audit (EXPERT)}

Dalam SEC (2003b) mendefinisikan keahlian keuangan Komite Audit, yang sifatnya luas dan menyatakan bahwa anggota Komite Audit dapat ditunjuk sebagai ahli keuangan jika anggota tersebut memiliki keahlian akuntansi (misalnya, auditor, CFO, pengontrol atau petugas akuntansi), atau jenis keahlian non-akuntansi (keuangan dan pengawasan) tertentu (misalnya, bankir investasi, analis keuangan, CEO atau presiden perusahaan) (Badolato et al., 2014). Pada penelitian ini variabel keahlian keuangan komite audit (EXPERT) akan diukur menggunakan dummy variabel.

EXPERT = 1 jika komite audit memiliki keahlian keuangan, 0 sebaliknya

\section{Gender (Jenis Kelamin) Komite Audit (ACFD)}

Adam dan Ferreira (2009) mengungkapkan bahwa dalam perilaku kerja, perempuan cenderung memiliki perilaku yang berbeda jika dibandingkan laki-laki. Sebagai contoh, dengan adanya dewan perempuan maka masalah presentasi ketidakhadiran lakilaki menjadi lebih kecil. Selain itu penelitian ini menemukan bahwa perempuan lebih cenderung ditempatkan pada tugas pengawasan seperti melakukan pengauditan dibanding laki-laki. Perempuan juga memiliki dampak signifikan dalam tata kelola pemerintahan, dikarenakan dewan yang lebih beragam akan lebih cenderung untuk meminta pertanggungjawaban CEO atas kinerja saham yang buruk. Sehingga dalam penelitian ini 
variabel gender (jenis kelamin) komite audit akan diukur menggunakan proporsi komite audit perempuan dibandingkan dengan jumlah anggota komite audit (Zalata et al., 2018). $\mathrm{ACFD}=$ proporsi komite audit perempuan dalam tim audit.

$$
A C F D=\left(\frac{j u m l a h \text { komite audit } \text { wanita }}{\text { total anggota komite audit }}\right) \times 100 \%
$$

\section{Ahli Keuangan Perempuan Komite Audit (FEMEX)}

Zalata et al. (2018) menunjukkan bahwa proporsi ahli keuangan perempuan di komite audit secara signifikan mempengaruhi dalam mengurangi manajemen laba dengan proporsi ahli keuangan laki-laki di komite audit tidak berpengaruh secara signifikan dalam manajemen laba. Sehingga dalam penelitian ini variabel ahli keuangan perempuan komite audit akan diukur menggunakan proporsi komite audit perempuan yang memiliki keahlian keuangan dibandingkan dengan jumlah anggota komite audit (Zalata et al., 2018).

FEMEX = proporsi ahli keuangan perempuan komite audit dalam tim audit

$$
F E M E X=\left(\frac{j u m l a h \text { ahli keuangan wanita komite audit }}{\text { total ang gota komite audit }}\right) x 100 \%
$$

\section{Ahli Keuangan Laki-laki Komite Audit (MALEX)}

Dalam penelitian Zalata et al. (2018) menyatakan walaupun proporsi laki-laki yang memiliki keahlian keuangan di komite audit tidak terlalu memiliki pengaruh signifikan terhadap manajemen laba, akan tetapi kehadiran laki-laki dengan keahlian keuangan lebih baik dalam mengurangi manajemen laba, dibandingkan laki-laki yang tidak memiliki keahlian keuangan. Sehingga dalam penelitian ini variabel ahli keuangan laki-laki komite audit akan diukur menggunakan proporsi komite audit laki-laki yang memiliki keahlian keuangan dibandingkan dengan jumlah anggota komite audit (Zalata et al., 2018).

MALEX = proporsi ahli keuangan perempuan komite audit dalam tim audit

$$
M A L E X=\left(\frac{\text { jumlah ahli keuangan pria komite audit }}{\text { total anggota komite audit }}\right) \times 100 \%
$$

\section{Metode Analisis Data}

Teknik analisis penelitian ini menggunakan analisis regresi linear berganda. Analisis regresi ditujukan untuk melihat pengaruh antara variabel bebas terhadap variabel terikat. Data 
diolah dengan menggunakan IBM SPSS 25 dan software Microsoft Excel 2010 untuk memperoleh hasil pengujian statistik yang akurat Persamaan regresi yang digunakan adalah sebagai berikut :

$$
\begin{gathered}
D A=\alpha_{o}+\alpha_{1} E X P E R T+\alpha_{2} A C F D+\alpha_{3} F E M E X+\alpha_{4} M A L E X+\alpha_{5} B S I Z E \\
+\alpha_{6} A C S I Z E+\alpha_{7} L O S S+\alpha_{8} L E V+\alpha_{9} O C F+\varepsilon
\end{gathered}
$$

\section{HASIL}

\section{Uji Asumsi Klasik}

Penelitian ini melakukan pengujian hipotesis dengan menggunakan model regresi linier berganda, sehingga sebelum melakukan uji regresi harus dilakukan uji asumsi klasik terlebih dahulu. Uji asumsi klasik terdiri dari uji normalitas, uji heteroskedastisitas, uji multikolinieritas, dan uji autokorelasi. Pengujian Normalitas pada model DA menunjukkan nilai Asymp. Sig (2-Tailed) sebesar 0,000 sehingga data dinyatakan tidak normal. Pembuangan data dilakukan sebanyak 6 kali dengan jumlah data yang dibuang sebanyak 79 sampel. setelah terjadi pembuangan data sebanyak 79 sampel yang menunjukkan nilai Asymp. Sig (2-tailed) 0.001, yang berarti data berdistribusi tidak normal karena nilai signifikan lebih kecil dari 0,05. Namun menurut Gujarati (2003), masalah normalitas tidak memiliki dampak yang cukup kritikal dalam pengolahan data jika data yang diolah memiliki jumlah sampel yang besar. Jumlah sampel dapat dikatakan besar jika jumlah sampel dalam suatu data melebihi 100 (Gujarati, 2003).

Hasil uji heteroskedastisitas menunjukkan bahwa semua variabel lulus uji heteroskedastisitas, kecuali untuk variabel MALEX, LOSS, OCF, dan BSIZE. Dimana tingkat signifikan MALEX, LOSS, OCF, dan BSIZE kurang dari 0,05. Akan tetapi variabel yang mengalami masalah heteroskedastisitas tetap bisa digunakan dalam penelitian, dikarenakan heteroskedastisitas tidak akan merusak konsistensi dan unbiasedness dari data yang digunakan (Gujarati, 2003).

Hasil uji multikolinieritas pada model regresi dalam penelitian ini terhindar dari masalah multikolinearitas atau dengan kata lain semua variabel independen tidak memiliki hubungan satu sama lain. Hal ini ditunjukkan dengan nilai VIF semua variabel lebih kecil dari 10 dan hasil Tolerance semua variabel lebih besar dari 0,1 .

Pengujian autokorelasi bertujuan untuk mengetahui adanya korelasi variabel dalam model regresi dengan menggunakan metode Durbin-Watson. Menurut Ghozali (2016), model 
regresi diterima jika hasil DU < DW < 4 - DU. Hasil DW berdasarkan adalah sebesar 2,002. Nilai tersebut lebih besar dari nilai DU untuk 850 perusahaan dengan 9 variabel yaitu sebesar 1,9063. Nilai DW juga masih lebih kecil dari 4- DU sebesar 2,0937, sehingga dapat disimpulkan bahwa 1,906 $<1,908<2,092$ atau DU $<$ D $<4$-DU sehingga model regresi ini telah lulus uji autokorelasi.

\section{Uji Regresi Linear Berganda}

Hasil persamaan regresi adalah sebagai berikut:

$$
\begin{aligned}
D A=0.097- & 0.016 E X P E R T+0.015 A C F D+0.024 F E M E X+0.044 M A L E X \\
& -0.001 L E V-0.082 L O S S-0.2940 C F+0.008 A C S I Z E+0.002 B S I Z E
\end{aligned}
$$

Hasil uji regresi linear menunjukkan nilai konstanta sebesar 0.097 yang berarti apabila variabel EXPERT, ACFD, FEMEX, MALEX, LEV, LOSS, OCF, ACSIZE, dan BSIZE memiliki nilai 0, maka DA akan bernilai 0.097. Nilai koefisien yang terdapat pada tabel diatas yaitu $\alpha 1, \alpha 2, \alpha 3, \alpha 4, \alpha 5, \alpha 6, \alpha 7, \alpha 8$, dan $\alpha 9$ menunjukkan besarnya perubahan dari DA sebagai variabel dependen apabila variabel independen dari regresi ini yaitu EXPERT, ACFD, FEMEX, MALEX, LEV, LOSS, OCF, ACSIZE, dan BSIZE mengalami kenaikan atau penurunan sebesar 1 satuan. Koefisien yang memiliki nilai positif seperti ACFD, FEMEX, MALEX, ACSIZE, dan BSIZE menunjukkan adanya hubungan yang searah antara variabel dependen dan independen. Misalkan ACFD meningkat 1 satuan maka nilai DA meningkat sebesar 0,010 satuan. Sedangkan untuk koefisien yang negatif yang terdapat pada variabel EXPERT, LEV, LOSS, OCF, maka menunjukkan adanya hubungan yang bertolak belakang dengan variabel dependen. Misalkan ketika nilai LEV meningkat 1 satuan maka nila DA akan mengalami penurunan sebesar 0,001 satuan. Sedangkan untuk dummy variabel yaitu EXPERT dan LOSS, jika dummy variabel satu (1) maka DA akan berubah sebesar nilai koefisien regresinya, sedangkan jika dummy variabel bernilai nol (0) maka nilai DA juga akan sebesar nol (0).

Penelitian ini menggunakan uji koefisien korelasi Pearson untuk menguji hubungan antara variabel dependen dengan variabel-variabel independen. Berdasarkan tabel 1 koefisien korelasi dalam penelitian ini menunjukkan bahwa variabel LEV, LOSS, OCF memiliki hubungan yang signifikan dengan DA. Bersamaan dengan itu variabel EXPERT, ACFD, 
FEMEX, MALEX, ACSIZE, dan BSIZE tidak memiliki hubungan yang signifikan dengan variabel dependennya yaitu DA. Terdapat tiga koefisien yang bernilai negatif yaitu LEV, LOSS, dan OCF, yang berarti nilai DA akan menurun seiring meningkatkannya variabel LEV, LOSS, dan OCF. Variabel independen lainnya yaitu EXPERT, ACFD, FEMEX. MALEX, ACSIZE dan BSIZE memiliki nilai korelasi positif sehingga peningkatan ACFD, FEMEX. MALEX, ACSIZE dan BSIZE dapat menyebabkan peningkatan DA.

Tabel 2. Hasil Uji Koefisien Determinasi $\left(\mathbf{R}^{2}\right)$

\begin{tabular}{lcccc}
\hline Model & $\mathbf{R}$ & $\begin{array}{c}\mathbf{R} \\
\text { Square }\end{array}$ & $\begin{array}{c}\text { Adjusted } \\
\text { R Square }\end{array}$ & $\begin{array}{c}\text { Std. Error of } \\
\text { the Estimate }\end{array}$ \\
\hline 1 & $0,383^{\text {a }}$ & 0,146 & 0,137 & 0,098 \\
a. Predictors: (Constant), BSIZE, FEMEX, LEV, EXPERT, ACSIZE, \\
LOSS, OCF, MALEX, ACFD \\
b. Dependent Variable: DA
\end{tabular}

Hasil uji koefisien determinasi dari model DA pada tabel 4.10. diatas menunjukkan nilai $\mathrm{R}$ sebesar 0,307 dan koefisien determinasi $\left(\mathrm{R}^{2}\right)$ sebesar 0,137 atau $13,7 \%$ yang artinya variabel EXPERT, ACFD, FEMEX, MALEX, LEV, LOSS, OCF, ACSIZE, dan BSIZE secara bersamaan dapat menentukan besarnya perubahan DA pada perusahaan sektor non keuangan yang terdaftar di Bursa Efek Indonesia periode 2016-2018 sebesar 13,7\% sedangkan sisanya yakni $86,3 \%$ perubahan DA dipengaruhi oleh faktor-faktor lain yang tidak dibahas dalam penelitian ini. 
Tabel 1. Rangkuman Hasil Koefisien Korelasi

\begin{tabular}{|c|c|c|c|c|c|c|c|c|c|c|}
\hline & DA & EXPERT & ACFD & FEMEX & MALEX & LEV & LOSS & OCF & ACSIZE & BSIZE \\
\hline DA & 1 & & & & & & & & & \\
\hline EXPERT & 0,029 & 1 & & & & & & & & \\
\hline ACFD & 0,042 & $-0,070^{*}$ & 1 & & & & & & & \\
\hline FEMEX & 0,058 & $0,121^{* *}$ & $0,856^{* *}$ & 1 & & & & & & \\
\hline MALEX & 0,066 & $0,313^{* *}$ & $-0,528^{* *}$ & $-0,438^{* *}$ & 1 & & & & & \\
\hline LEV & $-0,070^{*}$ & $-0,006$ & $-0,062$ & $-0,043$ & $-0,039$ & 1 & & & & \\
\hline LOSS & $-0,259^{* *}$ & $-0,015$ & $-0,030$ & $-0,029$ & 0,013 & $0,169^{* *}$ & 1 & & & \\
\hline $\mathrm{OCF}$ & $-0,172^{* *}$ & $-0,019$ & $-0,065$ & $-0,087^{*}$ & 0,001 & $-0,031$ & $-0,299^{* *}$ & 1 & & \\
\hline ACSIZE & 0,038 & 0,034 & $-0,010$ & 0,003 & $-0,076^{*}$ & $-0,009$ & $-0,117^{* *}$ & $0,093^{* *}$ & 1 & \\
\hline BSIZE & 0,048 & 0,048 & $-0,053$ & $-0,014$ & $-0,063$ & 0,026 & $-0,239^{* *}$ & $0,194^{* *}$ & $0,194^{* *}$ & 1 \\
\hline
\end{tabular}




\section{Tabel 3. Hasil Uji Signifikan Simultan (F-Test)}

\begin{tabular}{|c|c|c|c|c|c|c|}
\hline & Model & $\begin{array}{l}\text { Sum of } \\
\text { Squares }\end{array}$ & df & $\begin{array}{c}\text { Mean } \\
\text { Squar } \\
\text { e }\end{array}$ & $\mathbf{F}$ & Sig. \\
\hline \multirow{3}{*}{1} & Regression & 1,398 & 9 & 0,155 & 16,039 & $0,000^{b}$ \\
\hline & Residual & 8,152 & 842 & 0,010 & & \\
\hline & Total & 9,550 & 851 & & & \\
\hline
\end{tabular}

Hasil uji F dengan DA sebagai variabel dependen untuk semua model regresi menunjukkan nilai Sig. 0,000 yang berarti semua variabel independen sama-sama berpengaruh signifikan terhadap DA.

Tabel 4. Rangkuman Hasil Uji Parsial t-Test

\begin{tabular}{rlrl}
\hline & Model & t & Sig. \\
\hline & (Constant) & 2,835 & 0,005 \\
EXPERT & $-0,707$ & 0,480 \\
& ACFD & 0,508 & 0,611 \\
& FEMEX & 0,779 & 0,436 \\
& MALEX & 3,023 & 0,003 \\
& LEV & $-0,451$ & 0,652 \\
& LOSS & $-9,412$ & 0,000 \\
& OCF & $-8,029$ & 0,000 \\
& ACSIZE & 0,891 & 0,373 \\
& BSIZE & 0,864 & 0,388 \\
\hline
\end{tabular}

a. Dependent Variable: DA

Pada hipotesis 1 dalam penelitian ini ditemukan hasil bahwa kehadiran ahli keuangan di komite audit berpengaruh negatif secara tidak signifikan dengan nilai signifikan sebesar 0,240, sehingga mengakibatkan hipotesis satu (H1) dalam penelitian ini ditolak. Hasil penelitian ini konsisten dengan hasil penelitian Florencea dan Susanto (2018) yang juga tidak menemukan adanya hubungan signifikan antara kehadiran keahlian keuangan komite audit terhadap manajemen laba. Dechow et al., (1996) (dalam Nelson dan Devi., 2011) menyatakan bahwa para ahli komite audit yang memiliki pengalaman dan posisi manajerial seperti CEO dan atau CFO akan memberikan tingkat manajemen laba yang rendah. Jadi seorang komite audit dengan keahlian tetapi tidak memiliki pengalaman tidak akan memiliki pengaruh terhadap pengurangan manajemen laba. Qi dan Tan (2012) juga menemukan bahwa komite audit dengan pengalaman 
kerja dibidang keuangan dapat memantau manajemen laba perusahaan secara lebih efektif dibandingkan dengan komite audit yang tidak memiliki pengalaman tersebut dan tidak ditemukan hasil bahwa komite audit dengan tingkat pendidikan yang tinggi dapat bekerja sebagai pemantau yang efektif dibandingkan komite audit yang memiliki tingkat pendidikan yang rendah.

Budi (2010) dalam penelitiannya mengatakan bahwa ketidak signifikan yang terjadi antara kehadiran keahlian komite audit dan manajemen laba disebabkan karena banyak perusahaan membentuk komite audit hanya sebatas formalitas untuk memenuhi peraturan yang ada sehingga tidak terlalu memperhatikan kebenaran mengenai pengetahuan anggota komite audit baik dibidang akuntansi maupun keuangan dan akhirnya gagal mengurangi terjadinya manajemen laba. Hal ini yang menyebabkan jumlah komite audit yang memiliki latar belakang keahlian keuangan sangat tinggi dengan persentase sebesar 96,9\% sedangkan perusahaan dengan komite audit yang tidak memiliki latar belakang keahlian keuangan hanya sebesar 3,1\% . $3,1 \%$ ini merupakan jumlah yang relatif sangat kecil, sehingga tidak dapat mewakili data variabel EXPERT di Indonesia.

Hasil penelitian ini tidak konsisten dengan hasil penelitian dari Zalata, et al. (2018); Sun et al., (2012) yang menyatakan bahwa kehadiran anggota komite audit yang memiliki latar belakang keahlian keuangan akan mengurangi manajemen laba dalam perusahaan tersebut. Hal ini dikarenakan komite audit harus memiliki keterampilan, keahlian keuangan, dan pelatihan yang diperlukan untuk memenuhi tugas yang mereka lakukan. Dengan adanya kehadiran komite audit yang memiliki latar belakang keahlian keuangan diharapkan dapat membantu komite audit dalam memahami kompleksitas laporan keuangan dan untuk menghindari adanya agency theory antara kepentingan manajemen dan juga stakeholder perusahaan lainnya.

Pada hipotesis 2 dalam penelitian ini ditemukan hasil bahwa gender (jenis kelamin) komite audit berpengaruh positif secara tidak signifikan dengan nilai signifikan sebesar 0,611, sehingga mengakibatkan hipotesis dua (H2) dalam penelitian ini ditolak. Hasil penelitian ini signifikan dengan penelitian Abdullah dan Ismail (2015) yang menyatakan bahwa perempuan di dewan dan komite audit tidak mampu memainkan peran yang signifikan dalam membatasi dan mengurangi kecenderungan manajemen laba. Giovani (2013) dan Niskanen et al., (2011) menyatakan bahwa hasil yang tidak signifikan antara gender (jenis kelamin) komite audit dan manajemen laba diduga karena perempuan kurang menyukai risiko dari pada laki-laki, sehingga perempuan memiliki presentasi jabatan yang lebih rendah dari pada laki-laki. Sun et al., (2010) juga mengungkapkan bahwa tidak terdapat hubungan antara gender (jenis kelamin) anggota 
komite yang mempengaruhi efektivitas komite audit independen dalam menghambat terjadinya manajemen laba dalam perusahaan. Powell dan Ansic (1997) juga menyatakan bahwa perempuan lebih cenderung memiliki sikap yang lebih mudah dibujuk, kurang percaya diri, kurang agresif, dan memiliki kemampuan memimpin dan penyelesaian masalah yang rendah ketika membuat keputusan di bawah risiko.

Sun et al., (2010) berpendapat bahwa walaupun anggota komite audit perempuan lebih etis daripada anggota komite laki-laki, namun anggota komite perempuan tidak dapat mempengaruhi anggota komite lainnya. Hal ini dikarenakan adanya kemungkinan bahwa anggota komite laki-laki memiliki keyakinan yang tinggi mengenai manajemen laba dan menolak argumen dari anggota komite perempuan mengenai manajemen laba. Sehingga sulit untuk menguji sikap etika yang nyata pada anggota komite audit perempuan terhadap manajemen laba. Sebuah survei terhadap manajer dana di Amerika Serikat, Jerman, Italia, dan Thailand mengungkapkan bahwa perempuan lebih menolak risiko, kurang percaya diri dan lebih cenderung bergeser dari persaingan (Beckmann dan Menkhoff, 2008).

Proporsi perempuan yang lebih sedikit dibanding laki-laki ini disebabkan karena adanya persepsi atau fenomena yang telah diterima secara luas bahwa "dalam pekerjaan apapun dan dalam jabatan apapun semakin tinggi nilai, prestige, dan pengaruh maka proporsi perempuan akan semakin kecil" (Abdullah dan Ismail, 2015). Hal ini juga membenarkan fakta bahwa di Asia perempuan yang berkedudukan sebagai direktur sangatlah terbatas. Jika dilihat dari peraturan yang berlaku yaitu Peraturan Menteri Negara Badan Usaha Milik Negara (BUMN) Nomor: PER-12/MBU/2012 dan Peraturan Jasa Keuangan (OJK) Nomor: 55/POJK.04/2015 tentang "Pembentukan dan Pedoman Pelaksanaan Kerja Komite Audit" tidak ada pasal yang menjelaskan mengenai proporsi minimal jumlah perempuan yang harus terdapat di keanggotaan komite audit.

Hasil penelitian ini tidak sesuai dengan penelitian Zalata et al., (2017), Qi dan Tian (2012), Thiruvadi dan Huang (2011) Susanto (2016), dan Florencea dan Susanto (2018) yang menyatakan bahwa perbedaan gender (jenis kelamin) komite audit akan mempengaruhi manajemen laba dalam perusahaan. Qi dan Tian (2012), Shawver et al., (2006), dan Krishnan dan Parson (2008) menyatakan bahwa perempuan memiliki sikap yang tegas dan etis yang tinggi dari pada laki-laki serta memiliki moral yang tinggi, sehingga dapat meningkatkan manajemen laba. Selain itu dalam teori gender dikatakan bahwa perempuan lebih tidak memihak dan konservatif dibanding laki-laki. Secara keseluruhan komite audit perempuan atau 
pun direktur perempuan memiliki pengaruh yang signifikan terhadap kualitas laporan keuangan dan kemajuan perusahaan secara luas.

Pada hipotesis 3a dalam penelitian ini ditemukan hasil bahwa ahli keuangan perempuan komite audit berpengaruh positif secara tidak signifikan dengan nilai signifikan sebesar 0,436, sehingga mengakibatkan hipotesis tiga a (H3a) dalam penelitian ini ditolak. Hal ini sesuai dengan hasil dari hipotesis satu dan dua yang menyatakan tidak ada hubungan yang signifikan antara ahli keuangan dan komite audit perempuan pada manajemen laba. Abdullah et al., (2016) menyatakan bahwa mayoritas perempuan yang terdapat pada komite audit mungkin tidak memiliki keterampilan akuntansi dan keuangan yang diperlukan untuk mendeteksi manajemen laba. Pernyataan ini sesuai dengan fakta bahwa rata-rata ahli keuangan perempuan komite audit hanyalah sebesar $15,40 \%$, yang berarti dari $19,05 \%$ perempuan yang menjadi anggota komite audit hanya terdapat 15,40\% yang memiliki keahlian keuangan dan sisanya sebesar 3,65\% tidak memiliki latar belakang keuangan.

Walaupun perempuan memiliki kemampuan dalam menerima situasi dan pengetahuan, namun tidak dapat dipungkiri bahwa perempuan lebih mementingkan isi dari pada bentuk luarnya, sehingga membuat perempuan toleran terhadap kekurangan dan keraguan, sehingga perempuan menjadi lebih bersikap mengampuni. Dikatakan bahwa untuk mengubah dunia menjadi lebih adil dan damai maka perempuan harus meningkatkan kekuatan dan kemampuannya, serta mengembangkan pendidikannya, kemampuan berkomunikasi, pengorganisasian dan jaringan solidaritas nasional-internasional. Baik dalam keadaan terdidik maupun tidak terdidik, apresiasi terhadap perempuan masih berada dalam stereotip yang memprihatinkan. Dimana dalam hal ini perempuan dalam profesionalitas dan pekerjaannya lebih cenderung mengerjakan hal-hal yang bersifat membantu seperti sekretaris dan asisten. Akibatnya dalam hal ini laki-laki akan selalu menjadi pemimpin dan perempuan adalah yang dipimpin. (Murniati, 2004:73-81)

Qi dan Tan (2012) menyatakan bahwa tanpa adanya pengalaman maka walaupun komite audit memiliki pendidikan atau pengetahuan yang tinggi, komite audit akan lebih cenderung lebih lambat untuk menemukan adanya manajemen laba. Sehingga untuk hipotesis ini dapat disimpulkan bahwa ahli keuangan perempuan komite audit tidak signifikan dalam mengurangi manajemen laba disebabkan karena proporsi perempuan yang masih sangat sedikit di komite audit Indonesia serta walaupun komite audit perempuan memiliki keahlian keuangan tetapi tidak memiliki pengalaman dalam bidang tersebut maka kehadirannya tidak akan memberikan dampak terkait manajemen laba. 
Hasil penelitian ini tidak sesuai dengan penelitian Zalata et al., (2017) yang menyatakan bahwa semakin tinggi proporsi ahli keuangan perempuan di komite audit maka akan semakin efektif komite audit untuk menghambat terjadinya manajemen laba. Hal ini dikarenakan ahli keuangan komite audit yang melakukan mekanisme pemantauan yang signifikan diperoleh dari ahli keuangan komite audit perempuan. Shawver et al., (2006) akuntan perempuan yang bertanggung jawab terhadap IPO perusahaan lebih sensitif dan lebih kecil kemungkinannya untuk membuat suatu keputusan atau tindakan tertentu dibanding laki-laki.

Pada hipotesis $3 \mathrm{~b}$ dalam penelitian ini ditemukan hasil bahwa ahli keuangan laki-laki komite audit berpengaruh positif secara signifikan dengan nilai signifikan sebesar 0,003 , sehingga mengakibatkan hipotesis tiga $\mathrm{b}(\mathrm{H} 3 \mathrm{~b})$ dalam diterima. Akan tetapi hasil dari penelitian ini tidak sesuai dengan harapan bahwa dengan adanya proporsi laki-laki dengan keahlian keuangan di komite audit maka praktik manajemen laba akan semakin berkurang. Hal ini dikarenakan laki-laki memiliki kecenderungan yang risk taker dibandingkan dengan perempuan dalam bidang pengambilan keputusan keuangan (Gold et al., 2009). Byrnes et al., (1999) menyatakan bahwa orang yang lebih menyukai risiko maka akan cenderung melakukan hal-hal yang bersifat negatif. Powel dan Ansic (1999) menyatakan bahwa laki-laki lebih berisiko terhadap risiko dan lebih cenderung berfokus pada strategi yang menurut mereka akan mencapai keuntungan sebaik mungkin. Selain itu terdapat kecenderungan bahwa laki-laki menilai terlalu tinggi posisi mereka sehingga laki-laki lebih percaya diri terhadap keputusan mereka. Stinerock et al., (1991) (dalam Powel dan Ansic, 1997) juga menemukan bawa laki-laki memiliki preferensi risiko yang lebih tinggi dengan tingkat kecemasan yang rendah dalam pengambilan keputusan keuangan. Pendekatan sosialisasi gender berpendapat bahwa laki-laki dan perempuan membawa nilai-nilai yang berbeda ke tempat kerja yang akhirnya membentuk keputusan dan praktik mereka. Laki-laki juga memiliki kecenderungan untuk lebih mungkin melanggar peraturan dan melakukan tindakan yang tidak etis dibanding perempuan (Betz et al., 1989). Hal ini dikarenakan laki-laki lebih peduli untuk menghasilkan uang dan lebih maju di perusahaan (Krishnan dan Parsons, 2008).

Norman et al., (2011) menunjukkan bahwa dengan keahlian keuangan komite audit yang terdapat di perusahaan maka auditor internal perusahaan menjadi lebih mungkin untuk mengabaikan salah saji yang terdapat di perusahaan. Hal ini dikarenakan keahlian komite audit yang tinggi akan meningkatkan power komite audit. Power dalam hal ini adalah kapasitas atau potensi untuk mempengaruhi sikap atau perilaku orang lain meskipun ada penolakan. Kalbers dan Fogerty (1993) dalam Norman et al., (2011) menemukan bahwa manajer dan auditor 
internal mengakui keahlian sebagai sumber kekuatan komite audit, dan power theory menunjukkan bahwa ketika kekuatan komite audit meningkat maka manajemen akan memiliki lebih sedikit kemampuan untuk mempengaruhi keputusan auditor internal. Secara keseluruhan, literatur menunjukkan bahwa auditor internal akan menganggap komite audit lebih kuat dalam proses pelaporan keuangan ketika keahlian keuangan komite audit lebih tinggi, dan auditor internal akan lebih cenderung menyetujui tekanan manajemen untuk menghindari koreksi salah saji ketika komite audit memiliki keahlian lebih tinggi.

Penelitian ini juga menggunakan 5 variabel kontrol dengan hasil Leverage (LEV) merupakan variabel kontrol pertama dalam penelitian ini dan menjadi salah satu faktor yang mempengaruhi terjadinya manajemen laba. Hasil regresi leverage menunjukkan nilai signifikan sebesar 0.652dengan koefisien regresi sebesar -0,001 yang menunjukkan adanya pengaruh negatif yang tidak signifikan antara leverage dan manajemen laba dalam perusahaan. Dengan kata lain tidak terdapat pengaruh antara leverage dengan manajemen laba. Hal ini sesuai dengan penelitian Elfira (2014) yang menyatakan bahwa leverage tidak berpengaruh terhadap manajemen laba

Variabel kontrol kedua adalah LOSS, yang diukur dengan dummy variabel yaitu 1 jika perusahaan dalam periode berjalan mengalami kerugian dan 0 sebaliknya. Hasil regresi LOSS menunjukkan nilai signifikan sebesar 0.000 dengan koefisien regresi sebesar -0,082 yang menunjukkan adanya pengaruh negatif yang signifikan antara LOSS dan manajemen laba dalam perusahaan

Variabel kontrol ketiga adalah operating cash flow perusahaan (OCF). Hasil regresi OCF menunjukkan nilai signifikan sebesar 0.000 dengan koefisien regresi sebesar -0,294 yang menunjukkan adanya pengaruh negatif yang signifikan antara LOSS dan manajemen laba dalam perusahaan. Hasil penelitian ini didukung oleh penelitian yang dilakukan oleh Soliman dan Ragab (2014) yang menunjukkan bahwa arus kas dari aktivitas operasi secara signifikan dan negatif berkaitan dengan manajemen laba.

Variabel kontrol keempat dalam penelitian ini adalah ukuran audit komite (ACSIZE). Hasil regresi ACSIZE menunjukkan nilai signifikan sebesar 0,373 dengan koefisien regresi sebesar 0,008 yang menunjukkan adanya pengaruh positif yang tidak signifikan antara ACSIZE dan manajemen laba perusahaan. Hal ini sesuai dengan penelitian dari Cinthya dan Indriani (2015) yang menyatakan tidak ada hubungan yang signifikan antara ukuran komite audit dan manajemen laba. Hal ini dikarenakan ukuran komite audit ternyata tidak efektif dimana tujuan 
dari pembentukan komite audit adalah untuk meningkatkan kualitas laporan keuangan mengurangi adanya penyimpangan dalam pengelolaan perusahaan.

Variabel kontrol yang terakhir adalah board size (BSIZE) atau jumlah dewan direksi yang terdapat di perusahaan. Hasil regresi BSIZE menunjukkan nilai signifikan sebesar 0,388 dengan koefisien regresi sebesar 0,002 yang menunjukkan adanya pengaruh positif yang tidak signifikan antara BSIZE dan manajemen laba perusahaan. Hasil penelitian ini signifikan dengan penelitian yang dilakukan oleh Gulzar dan Wang (2011) dan Rahman et al., (2012) yang menemukan tidak ada hubungan yang signifikan antara ukuran dewan direksi dan manajemen laba.

\section{KESIMPULAN}

Tujuan dari penelitian ini adalah untuk menemukan dan menganalisis pengaruh dari variabel-variabel tertentu terhadap manajemen laba. Objek yang digunakan dalam penelitian ini adalah semua perusahaan non-keuangan yang terdaftar di Bursa Efek Indonesia periode 20162018 yang memenuhi kriteria sampel yang telah ditentukan. Hasil penelitian ini tidak terdapat pengaruh yang signifikan antara keahlian keuangan komite audit, proporsi wanita komite audit, dan keahlian keuangan wanita komite audit terhadap manajemen laba. Hal ini dikarenakan keahlian keuangan saja tidak cukup untuk mengurangi manajemen laba tetapi diperlukan juga pengalaman kerja di bidang keuangan dan intensitas pertemuan yang tinggi antara komite audit. Tidak terdapat pengaruh yang signifikan antara gender (jenis kelamin) komite dikarenakan perempuan lebih cenderung memiliki sikap yang mudah dibujuk sehingga menyebabkan perempuan akan lebih cenderung mengikuti arus yang ada dalam perusahaan. Walaupun perempuan cenderung bersikap etis namun perempuan tidak dapat menggerakkan orang lain untuk melakukan hal yang benar. Mayoritas perempuan yang terdapat di komite audit tidak memiliki keterampilan akuntansi dan keuangan yang diperlukan untuk mendeteksi manajemen laba. Sekalipun perempuan memiliki pendidikan dan pengetahuan akan tetapi terdapat stereotip bahwa perempuan akan selalu dipimpin oleh laki-laki dalam menjalankan tugasnya. Power theory menunjukkan bahwa ketika kekuatan komite audit meningkat maka manajemen akan memiliki lebih sedikit kemampuan untuk mempengaruhi keputusan auditor internal. Sehingga auditor internal akan memiliki sikap ketergantungan dan kepercayaan yang tinggi terhadap komite audit. 


\section{Keterbatasan dan Saran}

Berikut adalah keterbatasan dan kendala yang dihadapi oleh peneliti serta saran untuk penelitian kedepannya:

1. Variabel yang digunakan dalam penelitian ini tidak dapat sepenuhnya menjelaskan mengenai manajemen laba yang diukur dengan menggunakan discretionary accrual, hal ini dikarenakan variabel-variabel dalam penelitian ini hanya menjelaskan 8,5\% pengaruh terhadap manajemen laba. Penelitian selanjutnya dapat menambahkan variabel pengalaman untuk mendukung gender dan keahlian keuangan komite audit.

2. Penelitian ini masih menggunakan pengertian keahlian keuangan komite audit secara luas. Penelitian selanjutnya dapat mempersempit pengertian keahlian keuangan yang dimiliki oleh komite audit yang membedakan antara ahli akuntansi dan non-akuntansi.

3. Penelitian ini belum menggunakan semua perusahaan di Indonesia dan hanya meneliti perusahaan dalam periode 3 tahun terakhir. Peneliti selanjutnya dapat menggunakan sampel perusahaan yang lebih banyak dengan penelitian yang lebih lama.

\section{DAFTAR PUSTAKA}

Abdullah, S. N., \& Ismail, K. N. I. K. (2016). Women Directors, Family Ownership And Earnings Management In Malaysia. Asian Review of Accounting, Vol.24 Issue :4, pp.525-550.

Adams, R. B., \& Ferreira, D. (2009). Women In The Boardroom And Their Impact On Governance And Performance. Journal of Financial Economics, Vol. 94 Issue : 2, pp. 291-309

Badolato, P. G., Donelson, D. C., \& Ege, M. (2014). Audit Committee Financial Expertise And Earnings Management: The Role Of Status. Journal of Accounting and Economics, Vol.58 Issue : 3 , pp.208-230

Barua, A., Davidson, L. F., Rama, D. V., \& Thiruvadi, S. (2010). CFO Gender And Accruals Quality. Accounting Horizons. Vol.24 Issue: 1, pp. 25-39

Barua, A., Legoria, J., \& Moffitt, J. S. (2006). Accruals Management To Achieve Earnings Benchmarks: A Comparison Of Pre-Managed Profit And Loss Firms. Journal of Business Finance and Accounting, Vol.33 Issue:(5-6), pp. 653-670

Beckmann, D., \& Menkhoff, L. (2008). Will Women Be Women? Analyzing The Gender Difference Among Financial Experts. Kyklos, Vol.61 No.3, pp. 364-384

Betz, M., O’Connell, L., \& Shepard, J. M. (2013). Gender Differences In Proclivity For Unethical Behavior. Citation Classics from The Journal of Business Ethics: Celebrating the First Thirty Years of Publication, pp.427-432

Byrnes, J. P., Miller, D. C., \& Schafer, W. D. (1999). Gender differences in risk taking: A metaanalysis. Psychological bulletin, 125(3), 367.

CNN Indonesia, Tim. (2018, 26 September). Kronologi SNP Finance dari "Tukang Kredit" ke "Tukang Bobol". Dikutip dari: https://www.cnnindonesia.com/ekonomi/20180926143029-78333372/kronologi-snp-finance-dari-tukang-kredit-ke-tukang-bobol 
Cinthya, C. N., \& Indriani, M. (2016). Arus Kas, Komite Audit Dan Manajemen Laba Studi Kausalitas Pada Perusahaan Manufaktur Indonesia. Jurnal Dinamika Akuntansi Dan Bisnis, Vol.2 No.2, pp.167-183.

Florencea, N., \& Susanto, Y. K. (2019). Audit Committee: Woman, Experience, Education on Earnings Management, pp.17-21

Ghozali, Imam. 2016. Aplikasi Analisis Multivariete Dengan Program IBM SPSS 23 (Edisi 8). Cetakan ke VIII. Semarang: Badan Penerbit Universitas Diponegoro.

Gold, A., Hunton, J. E., \& Gomaa, M. I. (2009). The Impact Of Client And Auditor Gender On Auditors' Judgments. Accounting Horizons, Vol.23 No.1, pp.1-18.

Gujarati, D.N. (2003) Basic Econometrics. 4th Edition, McGraw-Hill, New York.

Gulzar, M. A., \& Zongjun, W. (2011). Corporate Governance Characteristics and Earnings Management: Empirical Evidence from Chinese Listed Firms. International Journal of Accounting and Financial Reporting, Vol.1 No.1, pp 133-151

Menteri Badan Usaha Milik Negara. 2002. Keputusan Menteri Badan Usaha Milik Negara Nomor: KEP117/M-MBU/2002. Tentang Penerapan Praktek Good Corporate Governance Pada Badan Usaha Milik Negara (BUMN). Indonesia: Menteri Badan Usaha Milik Negara

Kothari, S. P., Leone, A. J., \& Wasley, C. E. (2005). Performance Matched Discretionary Accrual Measures. Journal of Accounting and Economics, Vol.39 No.1, pp.163-197

Krishnan, J., \& Lee, J. E. (2009). Audit Committee Financial Expertise, Litigation Risk, And Corporate Governance. Auditing, Vol.28 No.1, pp.241-261

Krishnan, G. V., \& Parsons, L. M. (2008). Getting To The Bottom Line: An Exploration Of Gender And Earnings Quality. Journal of Business Ethics, Vol.78 No.1, pp.65-76

McNichols, M. F. (2003). Discussion Of "Why Are Earnings Kinky? An Examination Of The Earnings Management Explanation. Review of Accounting Studies, Vol.8 No.2, pp.385-391

Murniati, A. Nunuk. P. 2004. Getar Gender (Perempuan Indonesia dalam Perspektif Sosial, Politik, Ekonomi, Hukum, dan HAM. Magelang: Indonesia Tera

Niskanen, M., \& Karjalainen, J. (2011). Auditor Gender And Corporate Earnings Management Behavior In Private Finnish Firms. Managerial Auditing Journal, Vol.26 No.9, pp.778-793

Norman, C.A., Rose, Jacob M., \& Suh, Ik Seon. (2011). The Effect Of Disclosure Type And Audit Committee Expertise On Chief Audit Executives' Tolerance For Financial Misstatements. Accounting, Organization and Society, Vol.36, pp.102-108

Otoritas Jasa Keuangan. 2015. Peraturan Otoritas Jasa Keuangan Nomor 55 /POJK.04/2015 Tentang Pembentukan Dan Pedoman Pelaksanaan Kerja Komite Audit. Indonesia: Otoritas Jasa Keuangan

Powell, M., \& Ansic, D. (1997). Gender Differences In Risk Behaviour In Financial Decision-Making: An Experimental Analysis. Journal of Economic Psychology, Vol.18 No.6, pp.605-628

Puat Nelson, S., \& Devi, S. (2013). Audit Committee Experts And Earnings Quality. Corporate Governance: The International Journal of Business in Society, Vo.13 No.4, pp.335-351

Qi, B., \& Tian, G. (2012). The Impact Of Audit Committees Personal Characteristics On Earnings Management: Evidence From China. Journal of Applied Business Research (JABR), Vol.28 No.6, pp.1331-1344.

Rahman, R. A., \& Mohamed Ali, F. H. (2006). Board, Audit Committee, Culture And Earnings Management: Malaysian Evidence. Managerial Auditing Journal, Vol.21 No.7, pp.783-804

Rauf, F. H. A., Johari, N. H., Buniamin, S., \& Rahman, N. R. A. (2012). The Impact Of Company And Board Characteristics On Earnings Management: Evidence From Malaysia. Global Review of Accounting and Finance, Vol.3 No.2, pp.114-127 
Scott, William R. 2015.Financial Accounting Theory Seventh Edition. United State of America : Pearson Canada

Shawver, Tara J., Bancroft, P. and Sennetti, John T. (2006). Can the 'Clan Effect'Reduce the Gender Sensitivity to Fraud? The Case of the IPO Environment. Journal of Forensic Accounting, Vol.7, pp.185-208

Siska, Amelie F. D. (2014, 3 April). Enron, Skandal Besar Perusahaan Endergi yang Cekik Investor. Dikutip dari :

https://www.liputan6.com/bisnis/read/2031867/enron-skandal-besar-perusahaan-energi-yangcekik-investor?related=dable\&utm_expid=.9Z4i5ypGQeGiS7w9arwTvQ.1\&utm_referrer=

Simbolon, Harry Andrian.(2010, 15 Oktober). Sarbanes Oxlay Act. Dikutip dari :

https://akuntansiterapan.com/2010/06/15/sarbanes-oxely-act/

Soliman, M., \& Ragab, A. A. (2013). Audit Committee Effectiveness, Audit Quality and Earnings Management: An Empirical Study of the Listed Companies in Egypt. SSRN Electronic Journal, pp.1-29

Sun, J., Liu, G., \& Lan, G. (2011). Does Female Directorship on Independent Audit Committees Constrain Earnings Management? Journal of Business Ethics, Vol.99 No.3, pp.369-382

Susanto, Y. K. (2016). The Effect Of Audit Committees And Corporate Governance On Earnings Management: Evidence From Indonesia Manufacturing Industry. International Journal of Business, Economics and Law, Vol.10 No.1, pp.32-37

Thiruvadi, S., \& Huang, H. W. (2011). Audit Committee Gender Differences And Earnings Management. Gender in Management, Vol.26 No.7, pp.483-498

Xie, B., Davidson, W. N., \& DaDalt, P. J. (2003). Earnings Management And Corporate Governance: The Role Of The Board And The Audit Committee. Journal of Corporate Finance, Vol.9, pp.295316

Zalata, A. M., Tauringana, V., \& Tingbani, I. (2018). Audit Committee Financial Expertise, Gender, And Earnings Management: Does Gender Of The Financial Expert Matter?. International Review of Financial Analysis, Vol.55, pp.170-183

Zang, A. Y. (2012). Evidence On The Trade-Off Between Real Activities Manipulation and AccrualBased Earnings Management. Accounting Review, Vol.87 No.2, pp.675-703

Zhang, Y., Zhou, J., \& Zhou, N. (2007). Audit Committee Quality, Auditor Independence, and Internal Control Weaknesses. Journal of Accounting and Public Policy, Vol.26 No.3, pp.300-327 